\title{
Uncommon etiologies of infectious tonsillitis in adults
}

\author{
Adriana Bold ${ }^{1 *}$, Garofița Mateescu1', Gabriela Iliescu², Amalia Găman, Daniela Cernea \\ From The 9th Edition of the Scientific Days of the National Institute for Infectious Diseases Prof Dr Matei Bals \\ Bucharest, Romania. 23-25 October 2013
}

\section{Background}

Bacteria of the genus Actinomyces that colonize the oral cavity rarely cause infection. Fifty-percent of the cases of actinomycosis are in the cervicofacial area, more common in male patients and in infants. In most of cases, the onset of the disease occurs on the teeth or tonsils. Early diagnosis of cervicofacial actinomycosis has been reported in less than $10 \%$ of cases. The aim of this report is to emphasize less common etiologies in the diagnosis of adult patients with recurrent tonsillitis.

\section{Case report}

We report the case of a female patient, age 55, known with recurrent acute tonsillitis, hospitalized after two weeks of throat pain, dysphagia, odynophagia, cervical adenopathy, fever and intense asthenia, who remained symptomatic despite of oral cephalexin therapy. The clinical examination revealed hypertrophic palatine tonsils covered by exudates. After tonsillectomy, the diagnosis was carried out through biopsy of the tonsils. Histopathology revealed the infection with Actinomyces confirmed by PAS and Giemsa stains, with reactive hyperplasia of the subjacent lymphoid tissue. Specific rovamycin treatment for actinomycosis was administered for 14 days with general improvement of the clinical status.

\section{Conclusion}

Early diagnosis of actinomycosis enables appropriate and prompt treatment, thus preventing the involvement of other important areas.

\section{Authors' details \\ 'University of Medicine and Pharmacy Craiova, Romania. ${ }^{2}$ Emergency Clinical County Hospital Craiova, Romania.}

\footnotetext{
* Correspondence: adriana.bold@yahoo.com

'University of Medicine and Pharmacy Craiova, Romania

Full list of author information is available at the end of the article
}

Published: 16 December 2013

doi:10.1186/1471-2334-13-S1-P32

Cite this article as: Bold et al:: Uncommon etiologies of infectious tonsillitis in adults. BMC Infectious Diseases 2013 13(Suppl 1):P32.
Submit your next manuscript to BioMed Central and take full advantage of:

- Convenient online submission

- Thorough peer review

- No space constraints or color figure charges

- Immediate publication on acceptance

- Inclusion in PubMed, CAS, Scopus and Google Scholar

- Research which is freely available for redistribution

\section{() Biomed Central}

